\title{
Use of Journal Articles in English Language Classroom
}

\author{
Sagar Poudel
}

\begin{abstract}
Teaching English without any instructional materials may be difficult or even impossible. There are lots of materials which facilitate both the teachers and students in language teaching and learning. As with other teaching materials and resources, journal articles are also an important source for language teaching. Taking this into account, this article tries to explore how EFL teachers perceive the value of journal articles and how they use them in their classrooms. More specifically, the article tries to explore whether and to what extent journal articles can be used as instructional materials, and what strategies teachers employ to use journals articles to enhance language proficiency of their students.
\end{abstract}

Keywords: Journal, Articles, Sources, Levels, Academic writing

\section{Introduction}

Teaching English is a challenging job for teachers of English as foreign language (EFL) in Nepal. They basically depend on prescribed textbooks as they believe that textbooks are the sole source of learning materials. Instead of creating a motivational and encouraging environment, these teachers promote rigid and rigorous practice of course-book learning in the classroom. On the other hand, there are teachers who are conscious of the usefulness of academic/professional journals and articles and judiciously use them in their classroom. Due to advancements in science and technology, a variety of instructional materials such as books, journals, newspapers, and magazines are available in cyberspace.
Teaching can be made more effective and meaningful by adapting these materials and various techniques for teaching them. Teachers can guide their students to benefit from an extensive use of such materials, and journal articles could be one of those materials. Morrow (2009) believes that the use of journals improves writing fluency, provides practice with the mechanics of writing, and helps students choose topics and reflect on ideas. Harmer (2007) suggests that it is also always interesting to know what is going around us, and journal articles help students make better sense of that social context through learning. Similarly, Farmer (2008) suggests that news articles can also serve as a great teaching resource in the EFL classroom if they are structured well. Teachers can choose their own articles from newspapers or 
magazines based on the content to be taught, or as Dheram and Rani (2003) suggest, newspapers may be used for promoting learner autonomy in an international classroom with varying levels of English proficiency.

In addition, journal articles discuss current issues and, therefore, can be a valuable source of knowledge. By using journals as reading materials as well as a writing tool, students can feel connected to the social context and realities around them. The issues discussed in the journals help them absorb knowledge which is essential to them. The journals written on scientific, linguistic, ELT (English Language Teaching), sociology, business and the like, for example, can be beneficial for them to accomplish their goals of learning.

As a lecturer, the author of this article has used journal articles in the academic writing classes of the pre-service teacher education program for the last two years. Most contents in the program are about formal writing (i.e. how to write academic essays, how to conduct research and write report in English language and so on). Like any other novice teacher, the author initially looked for materials and resources top supplement the prescribed text of the course. The articles published in different academic journals were found to be useful and interesting to teach writing. The professional journals, for example, follow certain formats and include research and knowledge-based articles. Similarly, the articles which are published in English language journals usually follow the APA formats. For example, NELTA publishes academic, research-based articles. These articles benefit students in their personal and professional growth in that, as Tomlinson and Masuhara (2010) suggest, the affective/emotional involvement in academic activities with instructional materials is one way to sharpen knowledge. In this sense, the journal articles are more likely to connect the advance level students with various areas particularly related to teaching the English language. This article looks at the way English language teachers perceive the usefulness of journal articles and what strategies they employ to exploit them.

\section{Literature Review: Theoretical Framework}

Richards and Rodgers (2010) state that instructional resources perform a pivotal role in language teaching where task-based learning approaches exert an ample contribution to language learning and provide a basis for designing activities to practice language learning. Similarly, the use of instructional materials increases STT (Student Talk Time) and allows teachers to talk less i.e. minimizes TTT (Teacher Talk Time). Tomilson (2011) expresses the view that the materials that are used in the classroom provide authentic input for developing language skills. Therefore, instructional materials are needed to support teachers in teaching the students to integrate all language skills (listening, speaking, reading and writing). In a similar vein, Kitao and Kitao (1997) state that success in teaching is determined by the teaching resources, which are a fundamental asset in impacting what happens in the class.

There are different types of instructional materials that can be used in English language classrooms, in particular writing classrooms. Rai (2002) has discussed instructional materials under three main categories. 
Audio materials are typically used for developing listening skill of the learners; however, teacher can also teach other skills with the help of audio materials. Audio materials can be of different types such as radio, audio or voice recordings, CDs, tapes, etc. Visual materials include different materials that are easily available locally or can be prepared by teachers; they include maps, charts, photos, pictures, displays, posters, cards, magazines, newspaper, journals, handouts, postcards, pamphlets, brochure, manuals, officials' letters, notices, advertisements, and so on. (not relevant here). Audio-visual aids include both the sound and the visualization of pictures, , television, video clips, music, documentary, films, and so on. These materials appeal to both hearing and seeing. Articles or pieces of writing published in academic or scholarly journals with their standard format are known journal articles. Journals are periodical publications where scholars contribute or write on a particular discipline focusing on their research or a particular subject matter. Journals follow their predetermined formats. The articles published in such journals support learning and advance language skills as they relate to the learning of academic language through reviewing books and articles, writing essays, writing reports after field work, and conducting research. The present study attempts to explore how teachers teaching academic writing in English at various levels make use of some of these materials, especially journal articles.

\section{Research Questions}

The present study is based on the following research questions.

1) How do the journal articles help the students to learn English language?
2) What subject matters can be taught by using journal articles in EFL classes?

3) What kinds of changes can be brought in students' academic/formal writing by the use of journal articles?

\section{Participants and Research Tool}

In this research, a small scale survey was used where the information obtained from the participants was descriptively analyzed and discussed. The primary source of data was information from three teachers teaching English in higher secondary and bachelor levels in Kathmandu Valley. The participants for the study were teachers teaching in higher secondary and bachelor levels. For the purpose of collecting information, a purposive sampling procedure was adapted. Interviewing was employed as a research tool to collect information from the participants. Similarly, a small scale analysis of secondary sources like books, articles and other research studies was also conducted for supporting the discussion.

\section{Findings}

As discussed above, the objective of this study was to find out the usefulness of journal articles in Nepalese EFL classrooms. In this section, the information obtained from the primary sources are analysed and discussed. It consists of the information gathered by the open-ended questions. Open-ended questions on the use of journal articles were developed to get information from the teachers who are teaching in higher secondary and bachelor levels. The information obtained from the participants is discussed with the following themes.

Journals as a source of materials 
The EFL teachers teaching in different levels used various resources to facilitate their students' learning of the target language. This included any materials, programs, or software that helped the teacher present or explain his/her lesson better (Tomlinson, (1993) because the materials do not only support the teacher to present his/her lesson effectively, but also help the students to understand the text clearly and meaningfully. All teachers who participated in the survey used journal/ newspaper materials to enhance student learning. For example, Shiva Neupane, (pseudonym), an EFL teacher for higher secondary/ bachelor levels, responded that he used the materials which were available in the library or on the internet and that could be useful to the subject matters, including materials such as reference books, theses, postcards, etc., in general and newspaper, magazines, journals, and periodicals in particular. Similarly, Dinesh Khanal (pseudonym), another teacher, who taught primarily Bachelor of Education students, also said that he used the materials or resources which helped students develop language skills. He also used materials which could be bought from the market such as maps, charts and so on. He asserted that he checked the internet, audio/video clips, magazines, journals, encyclopedia and sometimes multimedia on a regular basis for articles and news clips. Another EFL teacher, Ramesh Shrestha (pseudonym) responded that he used the materials of his interest and as well as of his students from inside and outside the classroom. Besides this, he used newspaper, journals, periodicals, research papers, and magazines which he selected in accordance with the nature of the content he had to teach for a particular lesson. These practices show that the EFL teachers generally used such materials as newspaper, magazines, reference books, and audio/video, and in particular they used journals as a resource for teaching English language skills.

All teachers interviewed for the study believed that materials available on the internet and/or in journals are authentic materials. This is in line with Young (1999), who suggests that a regular use of journals with related courses builds the practical knowledge of both the students and teachers in the course of learning. The participating teachers used journal articles as a resource for teaching English language differently at different levels. One of them suggested that those articles could be used in higher secondary level as well, though to a limited extent all of them preferred to use journal articles for teaching advanced language skills with their advanced (Bachelor) level classes. It is evident that teachers preferred to use journal articles at an advanced level because of students' ability to interact and work with such materials.

\section{Subject matters taught using journal articles}

Articles are of various types and are written for different purposes. The articles included in academic/professional journals can be research-based, knowledge-based, experience-based, or they can be reviews of important works such as books, articles and so on. As Harmer (2007) views, teachers can make use of them for teaching various course contents because journals offer varieties, novelties, and motivation which can be supportive of teaching to write letters, reports and essays, make oral or written presentations, and write reviews and articles. More importantly, teachers can help students explore the experience to 
make them aware of the possibilities and opportunities regarding language learning.

Shiva, for example, used journal articles for teaching academic writing, i.e. formal writing. He affirmed that he used journal articles as a resource when the subject matters were writing essay, doing research, preparing reports, making citations, and listing references, reviews and so on. Similarly, Dinesh also made use of journal articles in most of his English language classes. He used research works published in journals for teaching formats like APA and MLA, for preparing research reports, and for teaching the formal features of writing. Ramesh also used them for teaching formal academic writing such as reports, essays, book reviews, or article reviews, and for teaching different formats as well. However, he expressed the view that the use of journal articles depended on the teachers' ideas and creativeness. He added that journal articles, for example, may be used to teach stylistics and sometimes literature as well since they are rich in literary features. As it can be deciphered, teachers generally used journal articles as a resource to teach various formal writing skills, but at the same time they used them for exploiting stylistic feature of the materials as well.

\section{Journal articles to support language learning}

As Wright (1976) asserts, resources of teaching language help learners to facilitate self-discovery and problem-solving, and support further improvement and progress in language development. In the present study, Shiva agrees with this view that use of journals articles enhanced students' language learning experience. He affirmed that the use of journal articles increased students' vocabularies, and helped explore personal experiences and creative writing.

For Dinesh, journal articles helped his students learn formal writing style, and explore ideas for reporting research, writing essays, and reviewing books and articles. They learned the formal writing formats, as well as citation and referencing styles. He further said that journal articles helped students develop their creative writing abilities, vocabulary stock, ideas of exploring personal experiences, and so on. Similarly, Ramesh said that the articles included in the journal were of advanced level and covered a wide range of issues and, therefore, supported the students to develop formal English language writing abilities together with the ability to report research studies.

\section{Changes observed after the use of journal articles}

It is evident from the above discussion that use of journal articles as a resource makes a difference in both teaching and learning. Regular and sensible use of such resources facilitates students' learning and helps to bring change in the classroom as well as in the students. Shiva, for example, observed that the use of journal articles encouraged students to get started with writing. He pointed out that his students started writing their stories and essays on the patterns they observed in various types of journal articles. In addition, his students developed the habit of practicing reflective writing based on their own experiences. Similarly, Dinesh found that his students started following the formats and structures of the journal articles. He further said that the students also learned the formats of reporting, citation and referencing when he provided exposure to 
the journals. More importantly, they became aware of formal writing styles. In the same way, Ramesh noticed changes in his students' writing. His students became more aware of the formal features of academic writing and followed them while producing their own academic assignments.

\section{Summary of Findings}

The survey found that the teachers used a range of resources such as reference books, newspaper, magazines, journals, periodicals, theses, internet and so on. However, the use of journal articles, together with other materials as a resource of teaching English, was most rewarding. The survey also revealed that the participants used journal articles in the advance level, i.e. in the bachelor's rather than the higher secondary level. This is understandable because, given the sophisticated style, language and content used in such materials, secondary level students simply cannot interact and engage with such materials fruitfully.

Similarly, the participants used journal articles to teach various language skills, particularly formal writing skills Basically, they used journal articles for teaching contents of academic writing such as essays, book/article reviews, and so on. One of the participants exploited the literary aspects of the journal materials as well, which is a creative use of such resources.

The participants found that the use of journal articles increased students' vocabulary, and helped students explore writing about personal experiences, develop critical and creative thinking, and learn how to write in a formal style It also provided guidelines for reviewing books and articles, and helped them learn style of citations and referencing. The participating teachers observed notable changes in their students, many of whom started engaging more in the class and writing academic assignments in the observed/discussed patterns or formats. For example, they wrote their essays in a more academic manner and learned the formats for reporting their own studies.

\section{Implication for Language Teachers}

The study has some limitations. Firstly, only a small number of teachers from one institution participated in the study. Secondly, the findings discussed in this study are based on their observations, and concrete examples for most of the claims made are not substantiated. Finally, the generalizations suggested or conclusions made may have limited applicability. Nevertheless, the study does provide instances that use of journal materials as a resource for language development has its merits. It has the following implications for teaching in EFL contexts. Firstly, journal materials are a useful resource for teaching English language skills in the Nepalese EFL setting. Such resources may be used in conjunction with or as a supplementary to other prescribed texts. Similarly, teachers may adopt and/or adapt journal articles in accordance with the need, demand and interest of the learners. Such articles as a teaching resource may be more useful for tertiary-level students, rather than secondary-level students. Therefore, teachers teaching advance-level students are likely to benefit more from their use. One other implication is that the use of journal articles is a way to enrich vocabularies, promote critical thinking and encourage creative writing. Teachers can use them to help students explore their 
experiences of language learning, provide ideas for academic writing, apply guidelines for writing academic assignments using formal writing patterns.

\section{References}

Baxter, J. S. (2009). Journals in the language classroom. English Teaching Forum.47(4), 22-26.

Brown, J. S., Collins, A. \& Duguid, P. (1989). Situated cognition and the culture of learning. Educational Researcher, 8(1), 32-42.

Dheram, P. \& Rani, N. (2003). Using English Newspapers in the ESL/EFL Classroom. The Internet TESL Journal. 13(3). Retrieved from - iteslj.org/ $\mathrm{T}$ e c h n i que s/ D h e r a m Newspapers.htm

Farmer, J. A, (2008, December). How to Effectively Use News Articles in the EFL Classroom. The Internet TESL Journal, 14(12). Retrieved from iteslj.org/Techniques / FarmerNews.html

Harmer, J. (2007). The practice of English language teaching. London: Longman.

Kitao, K. \& Kitao, S. K. (1997). Selecting and developing teaching/learning materials. The Internet TESL Journal, 5(4), retrieved from http://iteslj.org/ Articles/Kitao-Materials.html.

Morrow, L. M. (2009). Literacy development in the early years: Helping children read and write. Boston: Pearson.

Rai, V. S. (2002). English language teaching materials and practice. Kathmandu: Vhudipuran Prakashan.

Roth, W. - M., \& Jornet, A. G. (2013). Situated cognition. WIRES Cognitive
Science, 4, 463-478. doi:10.1002/ wcc.1242.

Richards, J.C. \& Rodgers, T.S. (2010). Approaches and methods in language teaching. Cambridge: Cambridge University Press.

Tomlinson, B. (1993). Materials development in language teaching. Cambridge: Cambridge University Press.

Tomilson, B. \& Masuhara, H. (2010). Research for materials development in language learning. London: Continuum.

Tomilson, N. (2011). Materials development in language teaching. Cambridge: Cambridge University Press.

Wright, A. (1976). Visual materials for language teachers. Harlow: Longman Publication.

Young, A. (1999). Teaching writing across the curriculum. ( $3^{\text {rd }}$ ed.). New Jersey: Prentice Hall.

\section{Contributor}

Sagar Poudel is an M. Ed. graduate from Tribhuvan University and is pursuing a M. Phil in ELE at Kathmandu University. He is currently working as an English Lecturer at Aadkikavi Bhanubhakta Campus, Tribhuvan University, Tanahun. He is also a Life Member of NELTA. His fields of interest are second language acquisition, sociolinguistics and English language teaching. Email poudelsagar1985@gmail.com 